The Cryosphere Discuss., doi:10.5194/tc-2016-32, 2016

Manuscript under review for journal The Cryosphere

Published: 11 April 2016

(c) Author(s) 2016. CC-BY 3.0 License.

\title{
Impacts of black carbon and mineral dust on radiative forcing and glacier melting during summer in the Qilian Mountains, northeastern Tibetan Plateau
}

\author{
Yang $\mathrm{Li}^{1,5^{*}}$, Jizu Chen ${ }^{2,5}$, Shichang Kang ${ }^{2,3^{*}}$, Chaoliu $\mathrm{Li}^{1}$, Bin $\mathrm{Qu}^{4}$, Lekhendra Tripathee ${ }^{1,5}$, Fangping Yan ${ }^{2,5}$, Yulan Zhang ${ }^{2}$, Junming Guo ${ }^{1,5}$, \\ Chaman $\mathrm{Gul}^{2,5}$, Xiang Qin ${ }^{2}$ \\ ${ }^{1}$ Key Laboratory of Tibetan Environment Changes and Land Surface Processes, Institute of Tibetan Plateau Research, Chinese Academy of Sciences, Beijing, 100101, China. \\ ${ }^{2}$ State Key Laboratory of Cryospheric Sciences, Cold and Arid Regions Environmental and Engineering Research Institute, Chinese Academy of Sciences, Lanzhou, 730000, China. \\ ${ }^{3}$ CAS Center for Excellence in Tibetan Plateau Earth Sciences, Beijing 100085, China. \\ ${ }^{4}$ Laboratory of Green Chemistry, Lappeenranta University of Technology, Mikkeli 50130, Finland. \\ ${ }^{5}$ University of Chinese Academy of Sciences, Beijing 100049, China.
}

Correspondence to: Y. Li (kerwinli@126.com) and S.-C, Kang (shichang.kang@lzb.ac.cn)

\begin{abstract}
Black carbon (BC) and mineral dust (MD), the most important compositions of light absorbing particles (LAPs), significantly reduce the albedo of glaciers and thus accelerate their melting. In order to investigate the impacts of $\mathrm{BC}$ and $\mathrm{MD}$ on the glacier radiation balance and ablation, a total of 92 surface snow/ice samples were collected along


Plateau (TP), during summer of 2013 and 2014. A thermal-optical method was employed to detect the BC (EC - element carbon) concentrations in snow/ice samples. The results showed that $\mathrm{BC}$ and $\mathrm{MD}$ concentrations were much lower in snow than those in ice, and gradually declined with increasing elevation. The effects of $\mathrm{BC}$ and $\mathrm{MD}$ on albedo reduction at different melting conditions were identified with the SNow ICe Aerosol Radiative (SNICAR) model initiated by in-situ observation data. The sensitivity analysis showed that BC had a stronger impact on albedo reduction than MD on this glacier. The impacts of BC represented around $45 \%$ of albedo reduction while the contribution of MD was $35 \%$ when the glacier surface presented as superimposed ice and experienced intensive melting. During summer, when the surface was covered by snow, BC and MD contributed for $15 \%$ and $9 \%$ respectively. On average, the radiative forcing (RF) caused by BC in the snow/ice, more than MD, was $41.6 \pm 37.0 \mathrm{~W} \mathrm{~m}^{-2}$. Meanwhile, compared to glacier melting in summer of 2013 and 2014 (409 mm w.e. and $366 \mathrm{~mm}$ w.e., respectively) calculated using the surface energy-mass balance model, contributions of BC and MD were less than $37 \%$ and $32 \%$ respectively of summer melting, while $\mathrm{MD}$ and $\mathrm{BC}$ together contributed a maximum of $61 \%$. This study provided the baseline information on BC and MD concentrations in glaciers of the northeastern TP and their contributions in glacier melting during summer.
\end{abstract}

\section{Introduction}

The Tibetan Plateau (TP) and the surrounding regions are known as the "Third Pole" of the Earth due to their immense area, high elevation, and are the largest reservoir of ice at low and middle altitudes (Yao et al., 2004, 2012; Qiu, 2008). The TP is also known as the "Water Tower of Asia", as it is the major freshwater source for more than 1.4 billion populations in the world (Cyranoski, 2005; Immerzeel et al., 2010). However, glaciers in this region have been undergoing rapid melting and shrinking (Yao et al., 2004, 2012; Qiu, 2008; Kang et al., 2010) and perhaps that could be accelerated due to the presence of light absorbing particles (LAPs) (Hansen and Nazarenko, 2004; Xu et al., 2009; Bond et al., 2013).

Black carbon (BC) and mineral dust (MD) (mainly hematite) are two primary types of LAPs, as they can immensely absorb the solar radiation in the atmosphere (Sokolik and Toon, 1999; Kandler et al., 2007; Ramanathan et al., 2007; Otto et al., 2009) and reduce albedo after being deposited on the cryosphere (Painter et al., 2007; Qian et al., 2009; Xu et al., 2009; Lau et al., 2010; Painter et al., 2010), thus enhancing absorption of sunlight, promoting snow/ice melting and causing positive climate warming feedback. These physical activities could alter the available amount of water resource in the region (Hansen and Nazarenko, 2004; Flanner et al., 2007; Qian et al., 2015). Numbers of researches have been done on understanding the relationship between BC/MD and albedo reduction as well as their radiative forcing (RF) on glacier melting (e.g. Ming et al., 2008, 2013; Flanner et al., 2009; Yasunari et al., 2010; Ginot et al., 2014; Kaspari et al., 2014; Qu et al., 2014; Gabbi et al., 2015; Wang et al., 2015). Albedo reduction by BC was $4-6 \%$ in the west of China (Ming et al., 2009) whereas average surface RF caused by BC was $1.5 \mathrm{~W} \mathrm{~m}^{-2}$ in the TP (Flanner et al., 2007) and varied from 0.8 to $12.1 \mathrm{~W} \mathrm{~m}^{-2}$ in the High Asian glaciers (Ming et al., 2013). Over the central TP, during the summer of 2012, average RF caused by MD and BC deposition on the Zhadang Glacier were found to be $2.7 \pm 3.4 \mathrm{~W} \mathrm{~m}^{-2}$ and $4.8 \pm 3.2$ $\mathrm{W} \mathrm{m}^{-2}$ respectively (Qu et al., 2014). Whereas in the southern flank of the Himalayan range (Nepal side), Yasunari et al. (2010) estimated that $2.0-5.2 \%$ albedo reduction caused by BC could lead to an increase of $70-204 \mathrm{~mm}$ of runoff in annual discharge at Yala glacier. Furthermore, the impact of BC represented less than $16 \%$ of annual potential melting while the contribution of MD and BC combined to surface melting represented a maximum of $26 \%$ in Mera Peak (Ginot et al., 2014). In addition, annual ablation was increased by $15-19 \%$ because of the combined impact of BC and Saharan dust, over the past one hundred years compared to pure snow conditions on Claridenfirn, Swiss Alps (Gabbi et al., 2015).

Since the glacier melting results in enrichment of $\mathrm{BC}$ and $\mathrm{MD}$ in the surface and further accelerates glacial melting; spatial discrepancy and its effects across a whole glacier were 
The Cryosphere Discuss., doi:10.5194/tc-2016-32, 2016

Manuscript under review for journal The Cryosphere

Published: 11 April 2016

(c) Author(s) 2016. CC-BY 3.0 License.

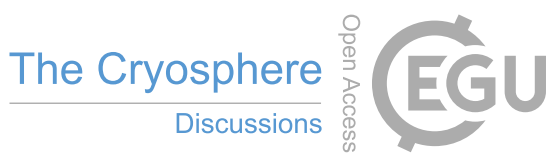

paid special attention, particularly in areas of high human impact and those surrounded by deserts. However, previous researches mostly focused on the BC and MD sampled from the accumulation area of glaciers (e.g. ice cores and snow pits), and only few paid attention to quantifying effects of BC and MD on albedo reduction, RF (Qu et al., 2014; Yang et al., 2015) and ablation for an entire glacier. Therefore, the primary purpose of this work is to describe the temporal and spatial distribution of BC and MD along the entire east tributary of Laohugou glacier No. 12 (LHG) on the northern TP during summer 2013 and 2014, to investigate the albedo reduction and RF caused by them under different melting conditions applying the SNICAR model, and to quantify the contributions of BC and MD to potential glacier melting using a glacier surface energy-mass balance model.

2 Methodology

\subsection{Description of research site}

The LHG, the largest and typical valley glacier in the western Qilian Mountains, northern TP $\left(39^{\circ} 10^{\prime}-35^{\prime} \mathrm{N}, 96^{\circ} 10^{\prime}-35^{\prime} \mathrm{E}, 4260-5481 \mathrm{~m}\right.$ a.s.1. $)$, is about $9.85 \mathrm{~km}$ long and covers an area of $20.4 \mathrm{~km}^{2}$ (Du et al., 2008). The climate of LHG is typically continental and arid, because of being controlled by the westerlies and the Siberian anticyclone (Zhang et al., 2013). The annual mean air temperature is $-9.3^{\circ} \mathrm{C}$ and $-11.9^{\circ} \mathrm{C}$ in the ablation zones and accumulation zones, respectively, whereas monthly mean air temperatures ranges from $18.2^{\circ} \mathrm{C}$ and $-22.7^{\circ} \mathrm{C}$ (December) to $3.4^{\circ} \mathrm{C}$ and $-0.7^{\circ} \mathrm{C}$ (July) in the ablation zones and accumulation zones (Sun et al., 2011; Li et al., 2012), respectively. Annual precipitation is $332.9 \mathrm{~mm}$ and around $68.1 \%$ occurs between May to September (Li et al., 2012). Meanwhile, this area is highly impacted by anthropogenic activities like intensive agriculture, grazing and industry, and surrounded by arid and semi-arid regions (e.g., Tarim Basin, Taklimakan Deser and Qaidam Basin) (Fig. 1). Whereas glacier area of the Laohugou river basin reduced by $11.59 \%$ in the past 50 years (Zhang et al., 2013), the LHG retreated $240 \mathrm{~m}$ during 1957 - 2005 (Du et al., 2008), elevation decreased by $18.6 \pm 5.4 \mathrm{~m}$ and the total volume lose was $0.218 \mathrm{~km}^{3}$ between 1957 and 2007 (Zhang et al., 2012).

\subsection{Field sampling and observation}

A total of 92 surface snow and ice $(0-5 \mathrm{~cm})$ samples were collected during July $27^{\text {th }}-29^{\text {th }} 2013$ and August $4^{\text {th }}-6^{\text {th }} 2014$, in replicate with an approximate altitude difference of 100 $\mathrm{m}$ and $50 \mathrm{~m}$ of the LHG on the eastern branch (Fig. 1). The glacier surface was covered by fresh snow due to frequent snowfall during sampling period of July 2013. Moreover, in such condition, the surface superimposed ice were sampled loaded with obvious MD below the snow. However, new-fallen snow samples were collected at August $4^{\text {th }} 2014$ after the precipitation, and the snow mostly melted at August $6^{\text {th }}$ when the superimposed ice samples were collected (Table 1). Snow/ice sampling procedure followed "Clean hands-Dirty Hands" principle (Fitzgerald, 1999). We collected three parallel snow samples and two ice samples in an area of $50 \times 50 \mathrm{~cm}^{2}$ and $5 \mathrm{~cm}$ depth at each site. The samples were preserved in NALGENE ${ }^{\circledR}$ HDPE wide-mouth bottles $(250 \mathrm{~mL})$ and were kept frozen during transportation until laboratory analysis. Snow density was measured with a balance and snow/ice grain sizes were observed by a hand lens (25x) with accuracy of $0.02 \mathrm{~mm}$ (Aoki et al., 2011). Albedo was measured as the fraction of the reflected and incoming shortwave radiation from the Kipp \& Zonen NR LITE radiometer (spectral range, 305-2800 nm). The sensors were mounted about $1.5 \mathrm{~m}$ high above the glacier surface on Automatic Weather Stations (AWS) located at $4550 \mathrm{~m}$ a.s.l.

\subsection{Laboratory analyses}

The sample-filtering method detailed by Cachier and Pertuisot (1994) and was similar to Xu et al. (2012) and the mass of insoluble MD was the discrepancy between the two weights before and after the filtration using a microbalance (accuracy: $0.1 \mathrm{mg}$ ). DRI ${ }^{\circledR}$ Model (2001A) was utilized to measure the OC/BC mass on the filters at the Institute of Earth Environment, Chinese Academy of Sciences, following a thermal-optical reflectance method of carbon analysis (Chow et al., 1993; Cao et al., 2003),

\subsection{Energy and mass balance model}

75 To assess the glacier melting caused by BC and MD, a distributed physical-based energy (SEB) and mass (SMB) balance model was used. The model can be described as following equations (1) and (2):

$$
\begin{aligned}
& B=\int\left(\frac{Q_{M}}{L_{m}}+\frac{Q_{L}}{L_{v}}+C_{m}+P_{\text {snow }}\right) d t \\
& Q_{M}=S^{\downarrow}(1-\alpha)+L^{\downarrow}+L^{\uparrow}+H+L E+Q_{G}
\end{aligned}
$$

Here, $B$ is the specific mass balance ( $\mathrm{mm}$ w.e.), whereas $Q_{M}$ and $Q_{L}$ correspond to the melt energy turbulent and latent heat flux, $L_{m}$ and $L_{v}$ are the latent heat of ice melt (3.34×105 $\left.\mathrm{J} \mathrm{kg}^{-1}\right)$ and evaporation/sublimation $\left(2.50 \times 106 \mathrm{~J} \mathrm{~kg}^{-1} / 2.83 \times 106 \mathrm{~J} \mathrm{~kg}^{-1}\right), C_{e n}$ and $P_{\text {snow }}$ refer to refreezing of melt water (not considered in model) and accumulation of solid precipitation, respectively. $S_{\downarrow}$ and $\alpha$ indicate the incoming solar radiation and the surface albedo, $L^{\downarrow}$ and $L^{\dagger}$ are the incoming and outgoing long-wave radiation, $H$ and $L E$ are the sensible and latent heat flux, respectively. $Q_{G}$ denotes the subsurface heat flux (Vincent, 2002; Yang et al., 2013). On the right side of Eq. (2), all energy components are defined as positive values when directed to the surface, otherwise they are defined as negative values.

The model is driven by the meteorological data (e.g. air temperature, relative humidity, wind speed and global radiation) collected at the AWS stations. Whereas $\alpha$, surface 
The Cryosphere Discuss., doi:10.5194/tc-2016-32, 2016

Manuscript under review for journal The Cryosphere

Published: 11 April 2016

(c) Author(s) 2016. CC-BY 3.0 License.

(c) (i)

temperature, turbulence fluxes are parameterized as Hock et al., (2005), Fujita et al., (2000) and Sun et al., (2014), respectively. In addition, $L^{\downarrow}$ is calculated as Duguay (1993); $L^{\uparrow}$ is calculated by Stefan-Boltzmann law from modeled surface temperature and surface emissivity (being set to 1 ). The parameters used in calculating of $L^{\downarrow}$ and $L^{\uparrow}$ are calibrated by measured incoming and outgoing long-wave radiation at AWS. Moreover, air temperature has a lapse rate of $6^{\circ} \mathrm{C} / \mathrm{km}$ with altitude, relative humidity and wind speed are assumed independent to altitude, and precipitation gradient is $8 \% / 100 \mathrm{~m}$ according to the measured value. Based on above parameterizations, SEB and SMB are calculated with $1 \mathrm{~h}$ temporal and $30 \mathrm{~m}$ spatial resolution. To assess the glacier ablation caused by BC and MD, we calculated the reduction of albedo with SNICAR model, and then the decreased albedo was coupled to albedo mechanism of SEB and SMB model, thus extra energy and glacier ablation affected by BC and MD could be calculated. In the coupled albedo mechanism, altitude effect is also considered, and the gradient value will be introduced in section 3.2 .

\section{Results \& Discussion}

\subsection{BC and MD concentrations and variations}

Altogether 52 surface snow samples and 40 ice samples were collected at fixed period repeatedly for measuring BC and MD concentrations. The daily variations of BC and MD concentrations in surface snow (Table 1) increased from fine-grained snow to firn because of post-depositional enrichment of LAPs (Conway et al., 1996; Wang et al., 2012). For instance, the average $\mathrm{BC}$ and MD concentrations were $60.5 \mathrm{ng} \mathrm{g}^{-1}$ and $6.0 \mu \mathrm{g} \mathrm{g}^{-1}(\mathrm{n}=7)$ respectively on July $27^{\text {th }}$, but increased to $160.1 \mathrm{ng} \mathrm{g}^{-1}$ and $17.5 \mu \mathrm{g} \mathrm{g}^{-1}(\mathrm{n}=7)$ respectively on July $28^{\text {th }}$. After a heavy snowfall on July $29^{\text {th }}$, however, BC and MD concentrations in fresh snow with an average of $849.3 \mathrm{ng} \mathrm{g}^{-1}$ and $67.9 \mu \mathrm{g} \mathrm{g} \mathrm{g}^{-1}(\mathrm{n}=7)$ respectively, were greatly higher than those observed in "aged snow". It was likely due to that atmospheric MD and pollutants were transported by the prevailing valley wind from deserts and highly polluted industrial centers (e.g., Jiuquan and Jiayuguan) towards the LHG region, which has been proved from the back trajectories analysis researches (Zhao et al., 2012; Dong et al., 2013, 2014; Xu et al., 2014). Past study over the same area has shown significant correlations between the daily mean BC concentration and relative humidity (Zhao et al., 2012). On average, contents of MD in snow reached $30.5 \pm 70.2 \mu \mathrm{g} \mathrm{g}^{-1}$, while $\mathrm{BC}$ concentration was $356.6 \pm 1248.1 \mathrm{ng} \mathrm{g}^{-1}$ in July 2013. As a result of drastic enrichment, the concentrations of BC and MD reached 20491.4 $\pm 19855.3 \mathrm{ng} \mathrm{g}^{-1}$ and $3528.7 \pm 3462.6 \mu \mathrm{g} \mathrm{g}^{-1}(\mathrm{n}=7)$ respectively in the bottom portion in July 2013. In addition, a heavy snow fell in $3^{\text {rd }}$ August 2014 and on the second day, there was a wide snowpack with an average depth of above $5 \mathrm{~cm}$ by visual inspection. The average contents of MD in snow were comparable with those of


$(\mathrm{n}=33)$, respectively, as a result of the snow melting and the BC and MD re-exposing when the surface was superimposed by ice in August of 2014. Therefore, the BC and MD concentrations in this work were much higher than earlier reported concentrations for snow pit samples in LHG (Dong et al., 2013; Ming et al., 2013) and corresponding figures recorded in ice cores and snow pits in West China (Kang et al., 1999; Ming et al., 2009; Xu et al., 2009; Wu et al., 2010; Wang et al., 2012, 2015). The discrepancy is mostly because the former works were focused on the accumulation area of glaciers (e.g. ice cores and snow pits) which were less drastic enrichment influenced.

Concentrations of BC and MD in snow/ice decreased with increasing elevation ("altitude effect") on LHG (Fig. 2), similar to that of Zhadang glacier (Qu et al., 2014), suggesting that most of $\mathrm{BC}$ and $\mathrm{MD}$ in atmosphere was deposited in the lower elevation (or ablation zone) at the beginning of snowfall, and that BC and MD were greatly enriched in the surface of the glacier during the melting season (Conway et al., 1996; Xu et al., 2006, 2012; Wang et al., 2012), particularly at the lower elevation of the glacier (Xu et al., 2009).

\subsection{Albedo reduction due to $\mathrm{BC}$ and MD depositions}

For this study, we used the in-situ BC and MD concentrations to investigate their impact on glacier energy and mass balance via changes in surface albedo. The online version of the SNICAR model (Flanner et al., 2007) was used to simulate the albedo declines produced by different magnitude of concentrations of BC and MD, with several simplistic assumptions. Here, we focused mainly on the albedo variation attributed to BC and MD (Table S1). To represent the melting caused by the particles on any given day, the following assumptions were made, (1) Surface spectral distribution (a. Mid-latitude winter, clear-sky, cloud amount < 5; b. Mid-latitude winter, cloudy-sky, cloud amount $\geq 5$ ); (2) the dust diameter was taken as 1.0-2.5 $\mu \mathrm{m}(5.0-10 \mu \mathrm{m})$ in snow (ice) (Dong et al., 2014); (3) The albedo of the underlying ground was taken as 0.2 in the visible band and 0.4 in the nearinfrared band; (4) The mass absorption cross-section (MAC) of BC was set as 1, which is the median of typical MAC values (Hadley and Kirchstetter, 2012); (5) incident radiation was selected direct and (6) volcanic ash concentration $\left(\mu \mathrm{g} \mathrm{g}^{-1}\right)$ was inserted as 0 in the model. In order to assess the contribution of BC and MD to the decreased albedo, we measured albedo as the fraction of the reflected and incoming shortwave radiation from the Kipp \& Zonen NR LITE radiometer. New-fallen snow can increase albedo above 0.8 , and the albedo decreased even below 0.2 as the snow melts and the BC and MD concentrating (Fig. 3). The average surface albedo of snow cover was 0.67 and 0.62 in July 2013 and August 2014 , respectively. Correspondingly, those of ice cover were 0.23 and 0.25 at the same period.

The simulations were designed for two different scenarios, i.e. assuming the addition of departures (slopes) of BC and MD on the average basis (Table 1). The separate effects of the above parameters on the albedo can be calculated using SNICAR model, and this method has been successfully used in the previous works (Ming et al., 2013; Qu et al., 2014). The results showed that BC and MD in the snow reduced the broadband albedo by $15 \%$ and $9 \%$, respectively (Fig. 4). BC and MD in ice here can reduce the albedo by 0.15 and 0.12, respectively, and BC and MD combined can reduce the broadband albedo by $70 \%$. A similar work done in the Zhadang glacier of western Nyainqentanglha (Qu et al., 2014), showed that $\mathrm{BC}$ and MD contributed less in the reduction of snow/ice albedo in Zhadang glacier in comparison to LHG. This can probably be due to the contents of BC and MD 
The Cryosphere Discuss., doi:10.5194/tc-2016-32, 2016

Manuscript under review for journal The Cryosphere

Published: 11 April 2016

(c) Author(s) 2016. CC-BY 3.0 License.

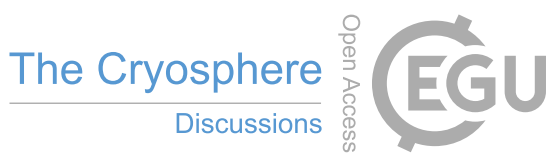

over LHG which were much higher than Zhadang glacier. Whereas the average albedo reduction by BC and MD in snow/ice decreased generally with increasing elevation (“altitude effect") on LHG (Table S1), the gradient value of BC and MD in snow (ice) were 0.0029/100 m and 0.0003/100 m (0.0164/100 $\mathrm{m}$ and $0.0172 / 100 \mathrm{~m})$, respectively.

\subsection{Additional absorbed radiative forcing}

BC and MD deposited on the glacier surface can absorb extra energy and accelerate glacier melting. The RF affects the glacier by increasing the cold snow's temperature in the accumulation area and melting the snow that reaches melting temperature in the ablation area (Kaspari et al., 2014). In order to assess the amount of excess absorbed solar energy due to the presence of $\mathrm{BC}$ and $\mathrm{MD}, \mathrm{RF}$ was estimated using the following equation:

$$
R F_{x}=R_{\text {in }- \text { short }} * \Delta \alpha_{x} \quad(3)
$$

where $R_{\text {in-short }}$ indicates incident short-wave solar radiation measured by Kipp \& Zonen Net Radiation LITE radiometer, $\Delta \alpha_{x}$ denotes the reduction of albedo as simulated by SNICAR model. In this work, we calculated the RF of snow/ice by the average daytime short-wave solar radiation during the whole July $2013\left(509 \mathrm{~W} \mathrm{~m}^{-2}\right)$ and August $2014\left(542 \mathrm{~W}^{-2}\right.$ ).

The simulation showed that the RF caused by BC and MD deposition on the LHG varied between 2.5-128.8 and 1.4-120.5 W m ${ }^{-2}$ (Table. S1), respectively. The RFs of BC exceeded MD in both snow and ice. On average, the RFs of MD in the summer of 2013 and 2014 was $30.7 \pm 32.9 \mathrm{~W}^{-2}$ and those caused by BC was $41.6 \pm 37.0 \mathrm{~W} \mathrm{~m}^{-2}$. These values are higher than those of Zhadang glacier (Qu et al., 2014), Muji glacier (Yang et al., 2015) during the 2012 glacier melting season, and the numerous modeling studies of BC RF conducted over the High Asia glaciers (Flanner et al., 2007; Qian et al., 2011; Ming et al., 2013; Nair et al., 2013) and those in the Arctic (Wang et al., 2011; Flanner et al., 2013), suggesting enrichment of BC and MD can absorb more solar radiation when the glaciers experienced strong melting, and the forcing over a whole glacier may be underestimated in the high altitude glacier regions.

\section{3 .4 Assessing glacier melting caused by $\mathrm{BC}$ and $\mathrm{MD}$}

BC and MD are likely to accelerate glacier melting and thus influence water resources on condition that the timing and magnitude of runoff is changed (Kaspari et al., 2014). We used the distributed surface energy-mass balance model (Hock, 2005) to quantify the effects on glacier ablation by BC and MD. The model calculated the components of the surface energy balance for every hour based on meteorological data collected at the AWS stations (Table 2).

A sensitivity analysis was performed to evaluate the sensitivity of the model results to the chosen input parameters (albedo reductions caused by BC and MD). Four scenarios of the impacts of LAPs on glacier ablation were examined: (1) entire ablation, (2) ablation except the impact of BC, (3) ablation except the impact of MD, and (4) ablation except the impacts of BC and MD combined. The simulated ablation caused by BC and MD deposition and concentrating on the LHG was shown as Fig. 5. Similarly, BC was the dominant factor on ablation during the summer. Overall, mean potential melting caused by BC alone was 143 mm w.e. while MD and BC combined was 236 mm w.e., compared to the summer's ablation of 2013 and 2014 measured using the mass and energy balance, i.e. $409 \mathrm{~mm}$ w.e. and 366 mm w.e. respectively, the mean impact of BC represented less than $37 \%$ of summer potential melting while the contribution of dust and BC combined to surface melting represented a maximum of $61 \%$, which was much higher than the effects of BC and MD sampled from firn/ice core on annual ablation in Mera Peak (Ginot et al., 2014) and Claridenfirn (Gabbi et al., 2015). During summer, precipitation and ablation is also at maximum over the glaciers in Qilian Mountains. Hence, glacier melting would be accelerated due to the exposure of BC and MD on the surface when the glacier melts at high rate. Whereas melting would result in the re-exposure of BC and MD at the glacier surface, and/or ablation season would be extended because of a warming climate (Fujita, 2007; Yasunari et al., 2010).

\section{Summary and conclusions}

To our knowledge, this study constitutes the first quantitative dataset of the impacts of LAPs on glacier ablation estimated directly from the northeastern edge of the TP. The average concentrations of $\mathrm{BC}$ and MD in surface snow and ice at LHG were much higher than those detected in snow pits and ice cores in TP and Tien Shan mountains. Moreover, the most remarkable finding in this study was that $\mathrm{BC}$ and MD concentrations were highest in surface ice (23890.6 $\pm 18411.0 \mathrm{ng} \mathrm{g}^{-1}$ and $2801.0 \pm 1948.7 \mu \mathrm{g} \mathrm{g}^{-1}$, respectively). The decreasing concentrations of $\mathrm{BC}$ and $\mathrm{MD}$ in surface snow/ice along with increasing elevation, mainly triggered by enrichment process of $\mathrm{BC}$ and $\mathrm{MD}$ during glacier melting, was more intensive in the ablation area than in the accumulation area. Under all covered conditions, $\mathrm{BC}$ in ice had the most significant contribution to albedo reduction (44.8\% $\pm 14.5 \%)$ and to $\mathrm{RF}$ $\left(81.6 \pm 24.6 \mathrm{~W} \mathrm{~m}^{-2}\right)$. Furthermore, the impact of BC contributed less than $37 \%$ of summer potential melting while MD and BC combined contributed a maximum of $61 \%$, indicating that $\mathrm{BC}$ rather than MD played the most important role in ablation of Qilian glaciers. Moreover, the albedo reduction, forcing and ablation caused by BC and MD in this study were also much higher than those determined in snow pits and ice cores in High Asia, indicating that the previous reports might have underestimated during intensive melting season, and thus the enrichment of $\mathrm{BC}$ and $\mathrm{MD}$ could absorb more solar radiation when the glaciers experienced strong melting, and the forcing over a whole glacier may be underestimated in the high altitude glacier regions. 
The Cryosphere Discuss., doi:10.5194/tc-2016-32, 2016

Manuscript under review for journal The Cryosphere

Published: 11 April 2016

(c) Author(s) 2016. CC-BY 3.0 License.

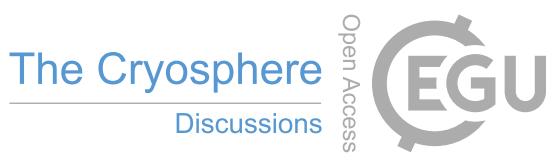

(c) (i)

\section{Acknowledgments.}

This study was supported by the Key Research Program of the Chinese Academy of Sciences (KJZD-EW-G03-04), the National Natural Science Foundation for Outstanding Young Scientist of China (41225002), National Basic Research Program of China (2013CBA01801) and the Foundation for Excellent Youth Scholars of CAREERI (CAS). We are very grateful to the staff of Qilian Shan Station of Glaciology and Ecologic Environment, Chinese Academy of Sciences. Mark Flanner and Mo Wang helped us to better understand the SNICAR model and the quantities used therein.

\section{References}

Aoki, T., Kuchiki, K., Niwano, M., Kodama, Y., Hosaka, M., and Tanaka, T.: Physically based snow albedo model for calculating broadband albedos and the solar heating profile in snowpack for general circulation models, J. Geophys. Res.-Atmos. (1984-2012), 116, D11114, 2011.

Bond, T., Doherty, S., Fahey, D., Forster, P., Berntsen, T., DeAngelo, B., Flanner, M., Ghan, S., Kärcher, B., and Koch, D.: Bounding the role of black carbon in the climate system: A scientific assessment, J. Geophys. Res.-Atmos., 118, 5380-5552, 2013.

Cachier, H., and Pertuisot, M. H.: Particulate carbon in arctic ice, Analusis, 22, M34-M37, 1994.

Cao, J. J., Lee, S. C., Ho, K. F., Zhang, X. Y., Zou, S. C., Fung, K., Chow, J. C., and Watson, J. G.: Characteristics of carbonaceous aerosol in Pearl River Delta Region, China during 2001 winter period, Atmos. Environ., 37, 1451-1460, 2003.

Chow, J. C., Watson, J. G., Pritchett, L. C., Pierson, W. R., Frazier, C. A., and Purcell, R. G.: The drithermal optical reflectance carbon analysis system-description, evaluation and applications in united-states air-quality studies, Atmos. Environ. A-Gen, 27, 1185-1201, 1993.

Conway, H., Gades, A., and Raymond, C. F.: Albedo of dirty snow during conditions of melt, Water Resour. Res., 32, $1713-1718,1996$.

Cyranoski, D.: The long-range forecast, Nature, 438, 275-276, 2005.

Dong, Z., Qin, D., Ren, J., Qin, X., Xu, J., and Sun, W.: Characteristics of atmospheric dust deposition in snow on the glaciers of western Qilian Mountains, Acta Geogr. Sin., 68, 25-35, 2013. (In Chinese with English abstract)

Dong, Z., Qin, D., Chen, J., Qin, X., Ren, J., Cui, X., Du, Z., and Kang, S.: Physicochemical impacts of dust particles on alpine glacier meltwater at the Laohugou Glacier basin in western Qilian Mountains, China, Sci. Total Environ., 493, 930-942, 2014.

Du, W., Qin, X., Liu, Y., and Wang, X.: Variation of the Laohugou Glacier No.12 in the Qilian Mountains, J. of Glaciol. Geocryol., 30, 373-379, 2008. (In Chinese with English abstract)

Duguay, C. R.: Radiation modeling in mountainous terrain - review amd status, MT. Res. Dev., 13, 339-357, 1993.

Fitzgerald, W. F.: Clean hands, dirty hands: Clair Patterson and the aquatic biogeochemistry of mercury, Clean hands: Clair Patterson Crusade against environmental lead contamination, Nova Science Publishers., 119-137, 1999.

Flanner, M. G., Zender, C. S., Randerson, J. T., and Rasch, P. J.: Present-day climate forcing and response from black carbon in snow, J. Geophys. Res., 112 , D11202, 2007.

Flanner, M. G., Zender, C. S., Hess, P. G., Mahowald, N. M., Painter, T. H., Ramanathan, V., and Rasch, P. J.: Springtime warming and reduced snow cover from carbonaceous particles, Atmos. Chem. Phy., 9, 2481-2497, 2009.

Flanner, M. G.: Arctic climate sensitivity to local black carbon, J. Geophys. Res.-Atmos., 118, 1840-1851, 2013.

Fujita, K., Ageta, Y., Pu, J. C., and Yao, T. D.: Mass balance of Xiao Dongkemadi glacier on the central Tibetan Plateau from 1989 to 1995 , Ann. Glaciol., $159-163,2000$.

Fujita, K.: Effect of dust event timing on glacier runoff: sensitivity analysis for a Tibetan glacier, Hydrol. Process., 21, $2892-2896,2007$.

Gabbi, J., Huss, M., Bauder, A., Cao, F., and Schwikowski, M.: The impact of Saharan dust and black carbon on albedo and long-term glacier mass balance, Cryosphere Discuss., 9, 1133-1175, 2015.

Ginot, P., Dumont, M., Lim, S., Patris, N., Taupin, J. D., Wagnon, P., Gilbert, A., Arnaud, Y., Marinoni, A., Bonasoni, P., and Laj, P.: A 10 year record of black carbon and dust from a Mera Peak ice core (Nepal): variability and potential impact on melting of Himalayan glaciers, Cryosphere, 8, 1479-1496, 2014.

Hadley, O. L., and Kirchstetter, T. W.: Black-carbon reduction of snow albedo, Nat. Clim. Change, 2, 437-440, 2012.

Hansen, J., and Nazarenko, L.: Soot climate forcing via snow and ice albedos, Proc. Natl. Acad. Sci., 101, 423-428, 2004.

210 Hock, R.: Glacier melt: a review of processes and their modelling, Prog. Phys. Geog., 29, 362-391, 2005.

Immerzeel, W. W., van Beek, L. P. H., and Bierkens, M. F. P.: Climate Change Will Affect the Asian Water Towers, Science, 328, 1382-1385, 2010.

Kandler, K., Benker, N., Bundke, U., Cuevas, E., Ebert, M., Knippertz, P., Rodriguez, S., Schuetz, L., and Weinbruch, S.: Che mical composition and complex refractive index of Saharan Mineral Dust at Izana, Tenerife (Spain) derived by electron microscopy, Atmos. Environ., 41, 8058-8074, 2007.

Kang, S., Qin, D., Yao, T., Wake, C. P., and Mayewski, P. A.: Summer monsoon and dust signals recorded in the Dasuopu firn core, central Himalayas, Chinese Sci. Bull., 44, 20102015, 1999.

Kang, S., Xu, Y., You, Q., Fluegel, W.-A., Pepin, N., and Yao, T.: Review of climate and cryospheric change in the Tibetan Plateau, Environ. Res. Lett., 5, 015101, 2010. 
The Cryosphere Discuss., doi:10.5194/tc-2016-32, 2016

Manuscript under review for journal The Cryosphere

Published: 11 April 2016

(c) Author(s) 2016. CC-BY 3.0 License.

(c) (i)

Kaspari, S., Painter, T. H., Gysel, M., Skiles, S. M., and Schwikowski, M.: Seasonal and elevational variations of black carbon and dust in snow and ice in the Solu-Khumbu, Nepal and estimated radiative forcings, Atmos. Chem. Phy., 14, 8089-8103, 2014.

Lau, W. K. M., Kim, M.-K., Kim, K.-M., and Lee, W.-S.: Enhanced surface warming and accelerated snow melt in the Himalayas and Tibetan Plateau induced by absorbing aerosols, Environ. Res. Lett., 5,025204, 2010.

Li, J., Qin, X., Sun, W., Zhang, M., and Yang, J.: Analysis on Micrometeorological Characteristic in the Surface Layer of Laohugou Glacier No.12 in Qilian Mountains, Plateau Meteorol., 31, 370-379, 2012. (In Chinese with English abstract)

Ming, J., Cachier, H., Xiao, C., Qin, D., Kang, S., Hou, S., and Xu, J.: Black carbon record based on a shallow Himalayan ice core and its climatic implications, Atmos. Chem. Phy., $8,1343-1352,2008$

Ming, J., Xiao, C., Cachier, H., Qin, D., Qin, X., Li, Z., and Pu, J.: Black Carbon (BC) in the snow of glaciers in west China and its potential effects on albedos, Atmo. Res., 92, 114-123, 2009.

Ming, J., Xiao, C., Du, Z., and Yang, X.: An overview of black carbon deposition in High Asia glaciers and its impacts on radiation balance, Adv. Water Resour., 55, 80-87, 2013.

Nair, V. S., Babu, S. S., Moorthy, K. K., Sharma, A. K., Marinoni, A., and Ajai: Black carbon aerosols over the Himalayas: direct and surface albedo forcing, Tellus B, 65, 14, 2013.

Otto, S., Bierwirth, E., Weinzierl, B., Kandler, K., Esselborn, M., Tesche, M., Schladitz, A., Wendisch, M., and Trautmann, T.: Solar radiative effects of a Saharan dust plume observed during SAMUM assuming spheroidal model particles, Tellus B, 61, 270-296, 2009.

Painter, T. H., Barrett, A. P., Landry, C. C., Neff, J. C., Cassidy, M. P., Lawrence, C. R., McBride, K. E., and Farmer, G. L.: Impact of disturbed desert soils on duration of mountain snow cover, Geophys. Res. Lett., 34, L12502, 2007.

Painter, T. H., Deems, J. S., Belnap, J., Hamlet, A. F., Landry, C. C., and Udall, B.: Response of Colorado River runoff to dust radiative forcing in snow, Proc. Natl. Acad. Sci., 107, 17125-17130, 2010

Qian, Y., Gustafson, W. I., Jr., Leung, L. R., and Ghan, S. J.: Effects of soot-induced snow albedo change on snowpack and hydrological cycle in western United States based on Weather Research and Forecasting chemistry and regional climate simulations, J. Geophys. Res. -Atmos., 114, D03108, 2009.

Qian, Y., Flanner, M. G., Leung, L. R., and Wang, W.: Sensitivity studies on the impacts of Tibetan Plateau snowpack pollution on the Asian hydrological cycle and monsoon climate, Atmos. Chem. Phy., 11, 1929-1948, 2011.

Qian, Y., Yasunari, T. J., Doherty, S. J., Flanner, M. G., Lau, W. K. M., Ming, J., Wang, H., Wang, M., Warren, S. G., and Zhang, R.: Light-absorbing Particles in Snow and Ice: Measurement and Modeling of Climatic and Hydrological impact, Adv. Atmos. Sci., 32, 64-91, 2015.

Qiu, J.: The third pole, Nature, 454, 393-396, 2008.

Qu, B., Ming, J., Kang, S. C., Zhang, G. S., Li, Y. W., Li, C. D., Zhao, S. Y., Ji, Z. M., and Cao, J. J.: The decreasing albedo of the Zhadang glacier on western Nyainqentanglha and the role of light-absorbing impurities, Atmos. Chem. Phy., 14, 11117-11128, 2014.

Ramanathan, V., Ramana, M. V., Roberts, G., Kim, D., Corrigan, C., Chung, C., and Winker, D.: Warming trends in Asia amplified by brown cloud solar absorption, Nature, 448, 575-U575, 2007.

Sokolik, I. N., and Toon, O. B.: Incorporation of mineralogical composition into models of the radiative properties of mineral aerosol from UV to IR wavelengths, J. Geophys. Res.Atmos., 104, 9423-9444, 1999.

Sun, W., Qin, X., Xu, Y., Wu, X., Liu, Y., and Ren, J.: Annual Variations of the Components of Radiation on the Laohugou No.12 Glacier in the Qilian Mountains, Adv. Earth Scie., 26, 347-354, 2011. (In Chinese with English abstract)

Sun, W., Qin, X., Du, W., Liu, W., Liu, Y., Zhang, T., Xu, Y., Zha, Q., Wu, J., and Ren, J.: Ablation modeling and surface energy budget in the ablation zone of Laohugou glacier No. 12, western Qilian mountains, China, Ann. Glaciol., 55, 111-120, 2014.

Vincent, C.: Influence of climate change over the 20th Century on four French glacier mass balances, J. Geophys. Res.-Atmos., 107, D19, 2002.

Wang, M., Xu, B., Zhao, H., Cao, J., Joswiak, D., Wu, G., and Lin, S.: The Influence of Dust on Quantitative Measurements of Black Carbon in Ice and Snow when Using a Thermal Optical Method, Aerosol Sci. Tech., 46, 60-69, 2012.

Wang, M., Xu, B., Cao, J., Tie, X., Wang, H., Zhang, R., Qian, Y., Rasch, P. J., Zhao, S., Wu, G., Zhao, H., Joswiak, D. R., Li, J., and Xie, Y.: Carbonaceous aerosols recorded in a southeastern Tibetan glacier: analysis of temporal variations and model estimates of sources and radiative forcing, Atmos. Chem. Phy., 15, 1191-1204, 2015.

Wang, Q., Jacob, D. J., Fisher, J. A., Mao, J., Leibensperger, E. M., Carouge, C. C., Le Sager, P., Kondo, Y., Jimenez, J. L., Cubison, M. J., and Doherty, S. J.: Sources of carbonaceous aerosols and deposited black carbon in the Arctic in winter-spring: implications for radiative forcing, Atmos. Chem. Phy., 11, 12453-12473, 2011.

Wu, G., Xu, B., Zhang, C., and Gao, S.: Atmospheric dust aerosols over the Eastern Pamirs: major element concentrations and composition, Environ. Earth Sci., 61, 1227-1237, 2010.

Xu, B., Yao, T., Liu, X., and Wang, N.: Elemental and organic carbon measurements with a two-step heating-gas chromatography system in snow samples from the Tibetan Plateau, Ann. Glaciol., 257-262, 2006.

Xu, B., Cao, J., Hansen, J., Yao, T., Joswia, D. R., Wang, N., Wu, G., Wang, M., Zhao, H., Yang, W., Liu, X., and He, J.: Black soot and the survival of Tibetan glaciers, Proc. Natl. Acad. Sci., 106, 22114-22118, 2009. 
The Cryosphere Discuss., doi:10.5194/tc-2016-32, 2016

Manuscript under review for journal The Cryosphere

Published: 11 April 2016

(c) Author(s) 2016. CC-BY 3.0 License.

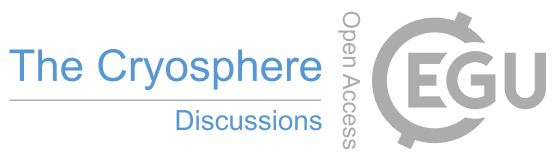

Xu, B., Cao, J., Joswiak, D. R., Liu, X., Zhao, H., and He, J.: Post-depositional enrichment of black soot in snow-pack and accelerated melting of Tibetan glaciers, Environ. Res. Lett., 7, 014022, 2012.

Xu, J., Wang, Z., Yu, G., Qin, X., Ren, J., and Qin, D.: Characteristics of water soluble ionic species in fine particles from a high altitude site on the northern boundary of Tibetan Plateau: Mixture of mineral dust and. anthropogenic aerosol, Atmos. Res., 143, 43-56, 2014.

Yang, S., Xu, B., Cao, J., Zender, C. S., and Wang, M.: Climate effect of black carbon aerosol in a Tibetan Plateau glacier, Atmos. Environ., 111, 71-78, 2015.

Yang, W., Yao, T., Guo, X., Zhu, M., Li, S., and Kattel, D. B.: Mass balance of a maritime glacier on the southeast Tibetan Plate au and its climatic sensitivity, J. Geophys. Res.Atmos., 118, 9579-9594, 2013.

Yao, T., Wang, Y. Q., Liu, S. Y., Pu, J., Shen, Y. P., and Lu, A. X.: Recent glacial retreat in High Asia in China and its impact on water resource in Northwest China, Sci. China Ser. D, 47, 1065-1075, 2004

Yao, T., Thompson, L., Yang, W., Yu, W., Gao, Y., Guo, X., Yang, X., Duan, K., Zhao, H., Xu, B., Pu, J., Lu, A., Xiang, Y., Kattel, D. B., and Joswiak, D.: Different glacier status with atmospheric circulations in Tibetan Plateau and surroundings, Nat. Clim. Change, 2, 663-667, 2012.

Yasunari, T. J., Bonasoni, P., Laj, P., Fujita, K., Vuillermoz, E., Marinoni, A., Cristofanelli, P., Duchi, R., Tartari, G., and Lau, K. M.: Estimated impact of black carbon deposition during pre-monsoon season from Nepal Climate Observatory - Pyramid data and snow albedo changes over Himalayan glaciers, Atmos. Chem. Phy., 10, 6603-6615, 2010.

Zhang, M., Qin, X., Du, W., Liu, Y., and Sun, W.: Glacier change in the Laohugou river basin monitored by remote sensing from 1957 to 2009 , J. Arid Land Resour. Environ., 27 , 70-75, 2013.(In Chinese with English abstract)

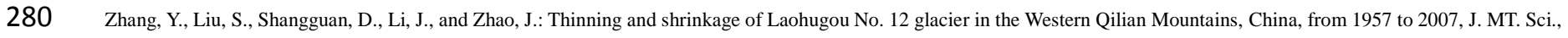
9, 343-350, 2012.

Zhao, S., Ming, J., Xiao, C., Sun, W., and Qin, X.: A preliminary study on measurements of black carbon in the atmosphere of northwest Qilian Shan, J. Environ. Sci., 24, 152-159, 2012. 
The Cryosphere Discuss., doi:10.5194/tc-2016-32, 2016

Manuscript under review for journal The Cryosphere

Published: 11 April 2016

(c) Author(s) 2016. CC-BY 3.0 License.

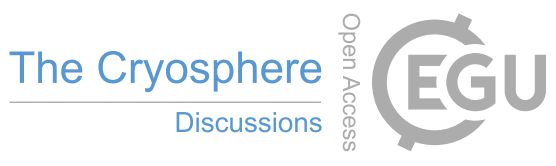

(c) (i)

285 Table 1. Sampling information: two expeditions were conducted on the LHG, and samples (snow/ice) were collected under six melting conditions of the glacier in the summer of 2013 and 2014. We collected two to three snow/ice samples at each site. In total, 52 snow and 40 ice samples were obtained for the conditions. The mean concentrations of BC and MD are listed here.

\begin{tabular}{|c|c|c|c|c|c|c|c|c|}
\hline Sample date & $\begin{array}{c}\text { No. of } \\
\text { samples }\end{array}$ & $\begin{array}{l}\text { Avg. of BC } \\
\text { conc. }\left(\mathrm{ng} \mathrm{g}^{-1}\right)\end{array}$ & $\begin{array}{l}\text { Avg. of MD } \\
\text { conc. }\left(\mu \mathrm{g} \mathrm{g}^{-1}\right)\end{array}$ & $\begin{array}{c}\text { Snow grain } \\
\text { size }(\mathrm{mm})\end{array}$ & $\begin{array}{c}\text { Snowpack density } \\
\left(\mathrm{kg} \mathrm{m}^{-3}\right)\end{array}$ & $\begin{array}{c}\text { Snowpack } \\
\text { Thickness (cm) }\end{array}$ & $\begin{array}{l}\text { Cloud amount } \\
(10=100 \%)\end{array}$ & Scene type \\
\hline 27 Jul 2013 & 7 & $60.5 \pm 21.1$ & $6.0 \pm 3.6$ & $0.2-0.4$ & 343 & 14 & 5 & Fine-grained snow \\
\hline 28 Jul 2013 & 7 & $160.1 \pm 93.0$ & $17.5 \pm 10.7$ & $0.3-0.7$ & 344 & 11 & 8 & Aged snow \\
\hline $29 \mathrm{Jul} 2013$ & 7 & $849.3 \pm 394.8$ & $67.9 \pm 17.5$ & $0.1-0.4$ & 250 & 18 & 8 & Fresh snow \\
\hline 4 Aug 2014 & 31 & $191.6 \pm 77.3$ & $27.9 \pm 9.3$ & $0.2-0.6$ & 258 & 8 & 4 & Fresh snow \\
\hline 6 Aug 2014 & 33 & $24920.3 \pm 17210.7$ & $2774.0 \pm 1827.4$ & $0.6-2.0$ & 400 & 1 & 6 & Superimposed ice \\
\hline
\end{tabular}


The Cryosphere Discuss., doi:10.5194/tc-2016-32, 2016

Manuscript under review for journal The Cryosphere

Published: 11 April 2016

(c) Author(s) 2016. CC-BY 3.0 License.

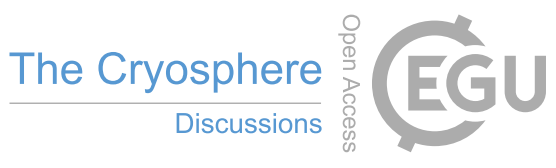

(c) (i)

Table 2. Technical parameters and installation heights of sensors on AWS

\begin{tabular}{|c|c|c|c|c|}
\hline Element & Sensor type & & Accuracy & Height (m) \\
\hline Air temperature $\left({ }^{\circ} \mathrm{C}\right)$ & Vaisala 41382 & & $\pm 0.2^{\circ} \mathrm{C}$ & $1.5,3.5$ \\
\hline Relative humidity (\%) & Vaisala 41382 & & \pm 2 & $1.5,3.5$ \\
\hline Air pressure $(\mathrm{hPa})$ & PTB 210 & & $\pm 0.5 \mathrm{hPa}$ & 1.5 \\
\hline Wind speed $\left(\mathrm{m} \mathrm{s}^{-1}\right)$ & Young 05103 & & $\pm 0.3 \mathrm{~m} \mathrm{~s}^{-1}$ & $1.5,3.5$ \\
\hline Wind direction $\left({ }^{\circ}\right)$ & Young 05103 & & $\pm 3^{\circ}$ & $1.5,3.5$ \\
\hline Shortwave radiation $\left(\mathrm{W} \mathrm{m}^{-2}\right)$ & CNR1 & \pm 10 & for daily total & 1.5 \\
\hline Longwave radiation $\left(\mathrm{W} \mathrm{m}^{-2}\right)$ & CNR1 & \pm 10 & for daily total & 1.5 \\
\hline Precipitation & Geonor T200B & & \pm 0.1 & 1.7 \\
\hline
\end{tabular}


The Cryosphere Discuss., doi:10.5194/tc-2016-32, 2016

Manuscript under review for journal The Cryosphere

Published: 11 April 2016

(c) Author(s) 2016. CC-BY 3.0 License.


(c) (i)

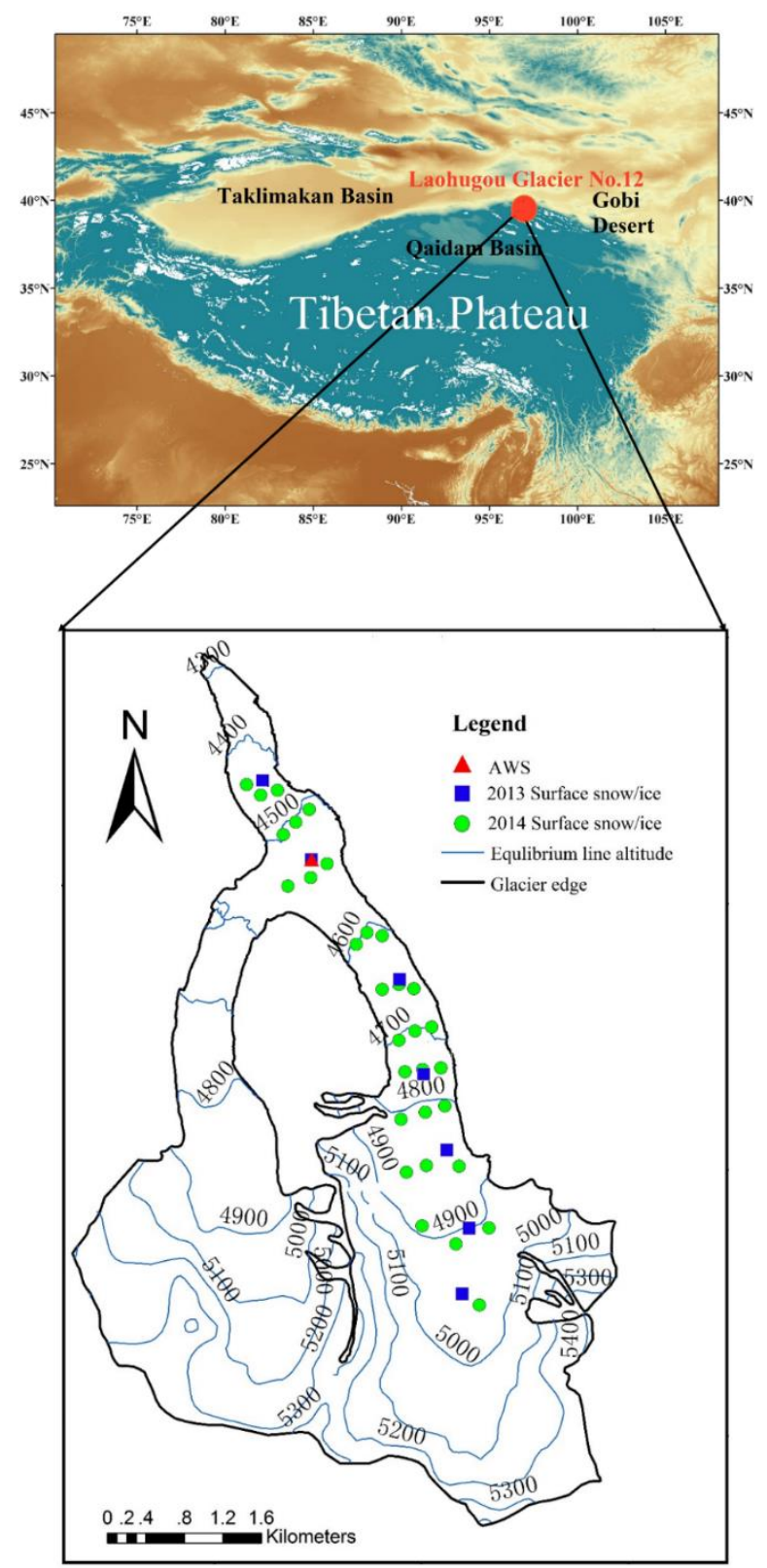

Figure 1. Topographic map of Laohugou glacier No.12 and sampling sites 
The Cryosphere Discuss., doi:10.5194/tc-2016-32, 2016

Manuscript under review for journal The Cryosphere

Published: 11 April 2016

(c) Author(s) 2016. CC-BY 3.0 License.
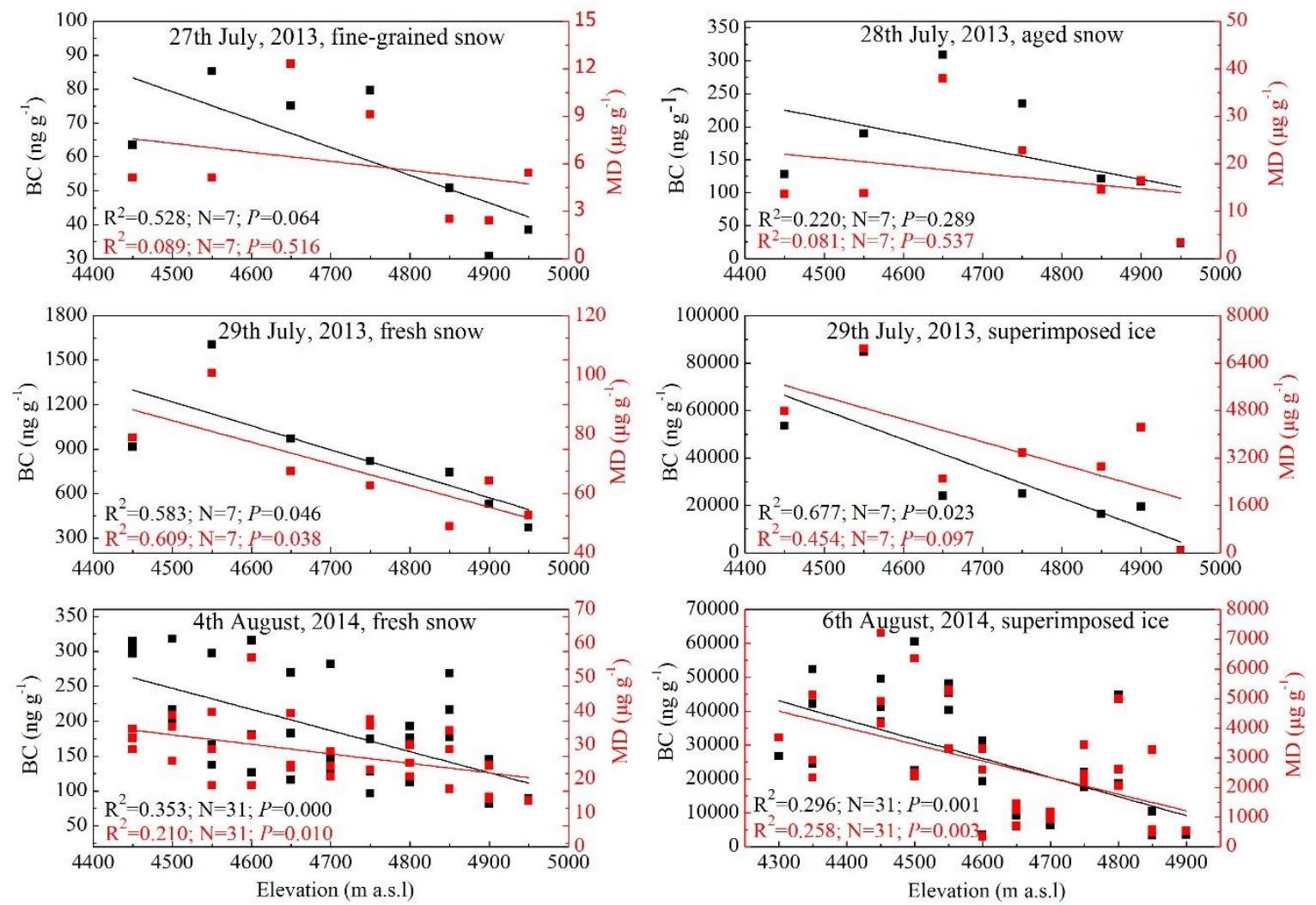

Figure 2. Variations of BC and MD in surface snow/ice from the Laohugou glacier No.12 with increasing elevation 
The Cryosphere Discuss., doi:10.5194/tc-2016-32, 2016

Manuscript under review for journal The Cryosphere

Published: 11 April 2016

(c) Author(s) 2016. CC-BY 3.0 License.

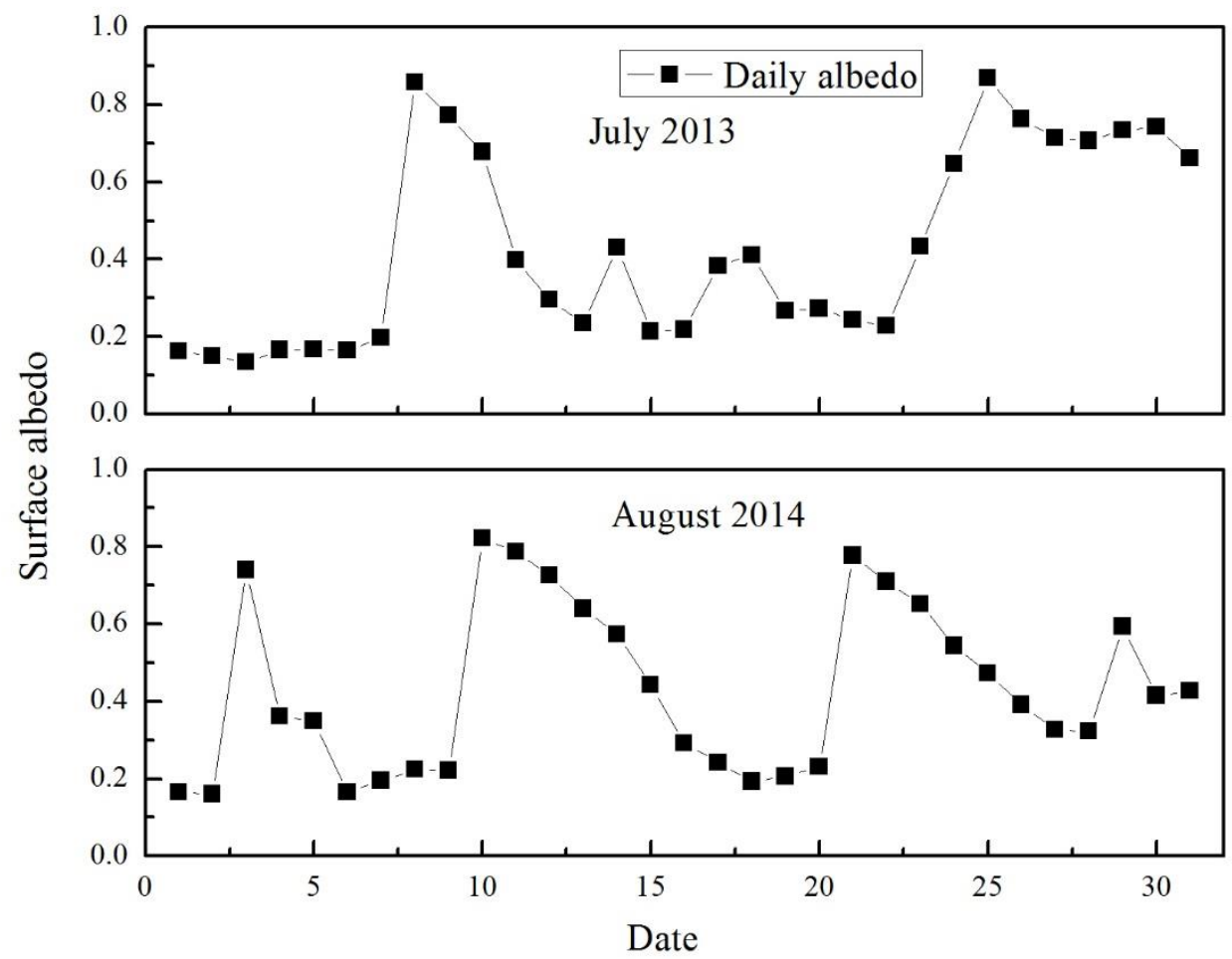

Figure 3. Variations of the surface albedo of the Laohugou glacier No.12 in July 2013 and August 2014 from the AWS. 
The Cryosphere Discuss., doi:10.5194/tc-2016-32, 2016

Manuscript under review for journal The Cryosphere

Published: 11 April 2016

(c) Author(s) 2016. CC-BY 3.0 License.


Figure 4. Mid-day RFs of BC and dust on the Laohugou glacier No.12 and the contribution (resulted from the SNICAR model) showing the reduction of albedo in surface snow cover area under three different melting conditions: (a) and (b), where the glacier was covered by snow of July 2013 and August 2014 , respectively; (c) and (d), where the glacier was covered by bare ice of July 2013 and August 2014, respectively; Error bars show the uncertainties. 
The Cryosphere Discuss., doi:10.5194/tc-2016-32, 2016

Manuscript under review for journal The Cryosphere

Published: 11 April 2016

(c) Author(s) 2016. CC-BY 3.0 License.

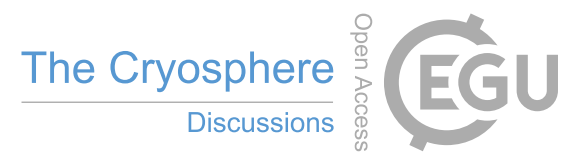

(c) (i)

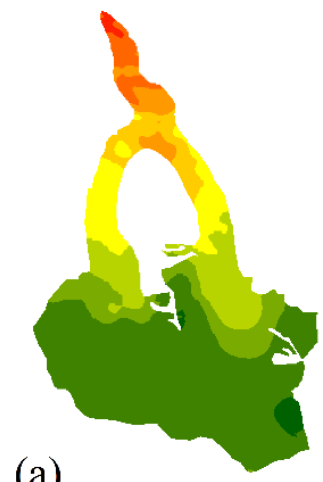

(a)

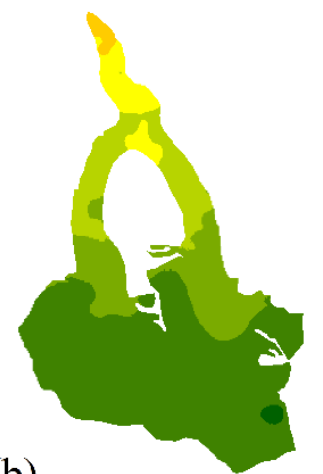

(b)

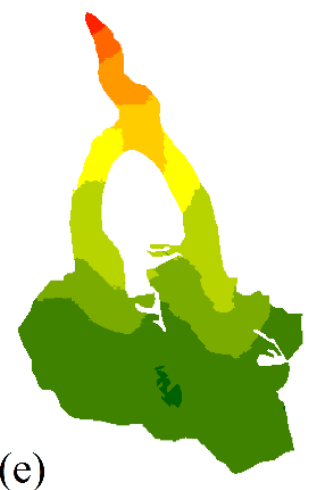

(e)



(c)
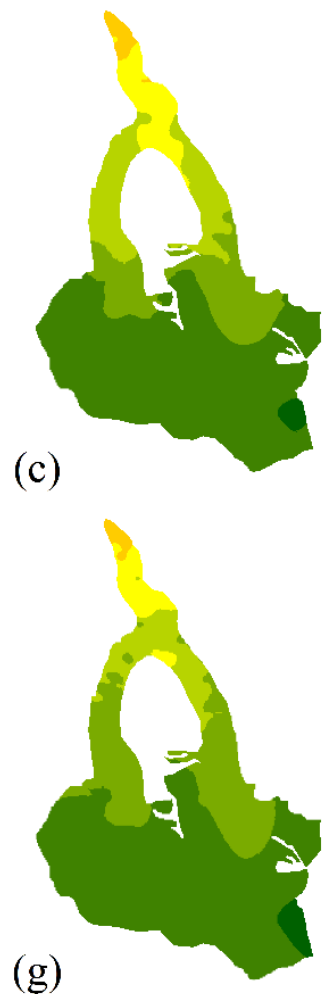

(d)



(h)



Glacier

ablation (mm)

$-250-0$

$0-250$

$\square 250-500$

$\square 500-750$

$\square 750-1,000$

$1,000-1,250$

$1,250-1,500$

$1,500-1,750$

$1,750-2,000$

Figure 5. Simulated glacier ablation caused by BC and MD. (a) and (e), actual ablation of 2013 and 2014,respectively; (b) and (f), actual ablation except the impact of BC of 2013 and 2014,respectively; (c) and (g), actual ablation except the impact of MD of 2013 and 2014,respectively; (d) and (h), actual ablation except the impacts of BC and MD combined of 2013 and 2014,respectively. 